\title{
Community Power Structure: The Gender Perspective
}

\author{
Linus Ugwu Odo and Dennis S. Aidolekhai
}

\begin{abstract}
The need to integrate the Nigerian women fully into the country's development process poses a challenge which cannot be ignored. This is because societal development or progress cannot be achieved where the needs and contributions of half of the population who are women are downgraded, marginalized or ignored. The paper interrogates the perceived or real marginalization of women in the scheme of things in Nigeria in the face of women's enormous propensity to contribute meaningfully to societal development. The study relied on secondary source of data collection and adopted "Decisional model" or approach as its analytical framework. The study found that woman's potential contributions to societal development whether at the community or national level are often neglected and wasted due to some archaic traditions about the status of women in the society. The paper recommended that women be accorded their pride of place to make useful contributions to the progress of the Nigerian nation.
\end{abstract}

Keywords - Community, development, gender, integrate, population, power.

\section{INTRODUCTION}

In Nigeria, the last few decades have witnessed unprecedented attention being focused on women's advancement in all spheres of life. The United Nations (UN) has been at the forefront of efforts to raise the status of women. It declared 1975 as International Women's Year and the years 1976-1985, as the United Nations' Decade for Women [1]. The UN also organized series of conferences on women in 1975 (Mexico City); 1980 (Copenhagen); 1985 (Nairobi); and 1995 (Beijing). At the African Regional level, similar conferences were held such as the 1989 conference in Abuja which produced the "Abuja Declaration on Women participation in Development: The Role of Women in Africa in the 1990s" [1].

The central theme of all these efforts has been the need to raise the status of women and bring them into the development process as equal partners with their male counterpart. In this respect, the various conferences have raised consciousness about age-old injustices and inequalities which women suffer in virtually all societies in the world. From all these efforts, the awareness has grown that women's woes have as their root cause, the question of gender. The status of Women has been interpreted differently based on each community's belief system, norms, and traditions around the world. It seems widely acknowledged that women constitute an oppressed, exploited and under privileged group particularly in Nigeria and other Third World countries [1].

This paper is a discussion of Community Power Structure with specific reference to its gender dimensions. The multi-

Published on October 21, 2021.

L. U. Odo, Department of Public Administration, Federal University, Gashua Yobe State, Nigeria. dimensional nature of community power structure and its main attributes raise serious questions as to whether a universally acceptable conceptualization of its character is possible. Community Power Structure has a significant gender dimension especially in terms of women's rights and access to institutional resources. Thus, to examine community power structure from a gender perspective would involve determining how and why women and men exercise power unequally. There is a clear persistent male-domination of power evident from an unevenly distributed nature of power.

Decisions that determine and shape the socio-economic policies usually lack women's input and thus tend to reflect the values, perspectives, and experiences of men. Thus, in most Nigerian communities, women are the worst neglected human group. They are denied ownership of land, they do not have access and control of productive resources thereby limiting and restricting their income generation activities, which in turn affects the economy and national development. The paper discusses these gender issues within the context of community power structure in Nigeria.

\section{A. Clarification of Concepts}

We shall attempt here to operationally define our key terms to enhance clear understanding of the subject matter and hence, place the discussion in proper perspective. These key terms are "Gender" and "Community Power Structure".

\section{B. Gender}

Since the 1970s, scholars such as Oakley have called attention to the fact that a lot of discrimination that women face on the grounds of their sex is baseless [1]. They distinguished between sex and gender, defining sex as biologically determined characteristics of men and women. Gender on the other hand, refers to all the characteristics of men and women, which a particular society has determined and assigned each sex. Thus, when a boy is chided, "Be a man", the speaker is not saying the boy risks changing his sex organs. Rather, "Be a man", is simply asking the boy to behave in ways expected of a member of the male sex in the society. This attitude is true of both the tradition and modem societies as discussed below.

\section{Traditional Society}

TABLE I: EXAMPLE OF SEX AND GENDER ROLES IN A TRADITIONAL SOCIETY [2]

\begin{tabular}{cc}
\hline \hline $\begin{array}{c}\text { Sex Roles (Biologically } \\
\text { Determined) }\end{array}$ & Gender Roles (Socially \\
& Determined) \\
\hline \hline Male:Impregnates Women & Bread winner and head of family; \\
& Strong, vigilant and adventurous \\
& $\begin{array}{c}\text { Protect family and clan; } \\
\text { Land owner; }\end{array}$
\end{tabular}

(e-mail: dr.odolinus1@gmail.com)

D. S. Aidolekhai, Department of Public Administration, IBB University, Niger State, Nigeria. 


\begin{tabular}{cc}
\hline \hline & Takes part in village councils and \\
governance; \\
Never cries or displays emotions; \\
Engage in male games such as \\
wrestling; etc. \\
Rears Children \\
Takes care of domestic chores; \\
Fetches and carries water and \\
firewood; \\
Does not own land; \\
Female:Becomes Pregnant; \\
Bears Children, \\
Breastfeeds child \\
council or governance; The \\
Phenomenon of Femicide and the \\
Greek Experience \\
Is weepy and emotional; \\
Engages in female games such as \\
dancing; etc.
\end{tabular}

\section{Modern Society}

Gender stereotypes are also very much in evidence in modem societies. The man is still the bread winner and head of family. Men govern and rule the society. They are captains of industry, commerce, and banking. They work as generals in the army, engineers, pilots, brain surgeons, business entrepreneurs, etc. At the end of the working day, men relax in front of the television, listen to radio, or read newspapers; they may also go out to the club, etc. Women, on the other hand, rear children, look after the home and do all the domestic chores, etc. If and when women go out to work, they usually work as teachers, nurses, secretaries, caterers, etc. At the end of the day's job, they still must dash into the kitchen to see to the evening meal and do all other domestic chores.

Gender stereotyping permeates the school system also, manifesting in both direct and subtle ways. For instance, there are "masculine" subjects such as science, technology, and mathematics. There are similarly, "feminine" subjects such as Home Economics, Literature and Secretarial Studies [1]. The language and illustrations used in textbooks and readers also betray a gender bias. For example, boys are generally portrayed as brave, intelligent, decisive, and adventurous, whereas girls are shown as shy and timid. Also, classroom interactions between teachers and pupils favor boys to the detriment of girls. Thus, in mixed schools, the undoubted class monitors, and school captains appointed by teachers are boys.

Gender is, therefore, important in the sense that whatever concept of gender a society holds regulates all spheres of existence of the individual from child to adulthood. In most Nigerian communities, gender roles have shackled women to the floor, preventing them from participating in, and benefiting from development efforts. However, it is argued that countries that have raised the status of their women educationally, socially, politically, and economically, generally enjoy a high standard of living and vice-versa [1].

We shall, for the purpose of this paper accept and apply the social definition of gender as it relates to both women and men in the analysis of the gender dimension of community power structure.

\section{E. Community Power Structure}

The Conceptualization of the term power is central to any proper understanding of the concept of community power structure and in particular, its gender dimensions. Power as a political phenomenon rest outside of oneself but is associated with making binding decisions on one [3]. It is also argued that power does not always reside with the occupants of formal positions because formal decision-makers may not always be the real decision-makers in a political system. The concept of power is, therefore, ambiguous and very elusive with much Controversy over its definition. Max Weber, according to [4], defined power as the probability that one actor within a social relationship will be in a position to carry out his own will despite resistance, regardless of the basis on which this probability rests. Dahl relying upon Max Weber's definition of power said that his intuitive idea of power was that " $A$ " would be said to have power over "B" to the extent that " $A$ " can get " $B$ " to do something that " $B$ " would not otherwise do.

According to this formulation, power can be an individual or micro property or a community or macro property. It is the capacity of the community to manipulate the economic, social, and cultural spheres in which the individual operates. Therefore, in the context of our discussion, we define community power structure as the power relation among principal actors in the community persisting through time.

However, the initial problem of any study of community power has been how to operationalize the concept of community power to render it amenable to measurement and investigation. The paper examined below a theoretical framework, which would elicit the understanding of the dynamics of the community power structure, particularly its gender dimensions.

\section{F. Theoretical Framework}

The study had attempted to define the concepts of Gender and Community Power Structure to operationalize them to render the subject matter amenable to measurement and investigation. Here, the paper would examine three models, which can independently be used to analyze the gender dimension of community power structure. The application of any one of the models to our discussion, therefore, reflects only one of possible theoretical frameworks that can be adopted for such analysis. In what follows, the paper seeks to discuss the major formation of each of the three models without allowing itself to be bug down by the details. These models are Positional; Reputation and Decisional [4].

\section{G. Positional Approach or Model}

The oldest method of studying community leadership is through the positional approach. It assumes that leader performs specified government and organizational roles. It is further assumed that occupants of such positions as Chairman of local government; Councilor, District Heads, Head of community Dispensary/Clinic; Headmaster/principals of community primary/Secondary schools, Chairperson of Rural Women Association, etc. are community leaders. The positional approach rests upon the probability that holders of governmental and organizational positions can and do exercise influence, which though not totally justified is not altogether unrealistic.

However, the major difficulty with the model is that it may be both too inclusive and too exclusive. Without independent verification, one never knew whether he has included leaders who are merely titular heads or excluded leaders who may exercise considerable power. Also, a particular set of positions may encompass the real leaders in one community 
but not in another.The positional approach assumes that all office holders are approximately equally powerful on every issue. But in real life situations, the possibility is that government office holders may be most influential on some issues while non-governmental leaders may dominate on others. Therefore, the positional approach may be useful for some purposes but doubtful as a means of identifying the real power holders in some communities.

\section{H. Reputation Approach or Model}

The reputational approach also known as elitist or power elite model has the tendency of assuming that reputed power is actual power. It assumes that if people feel a person or persons have power or its resources then the power is possessed and employed.

The earliest and still the most significant reputational study of community power structure is Floyd Hunter's study of Atlanta [4]. The picture of community power painted by Hunter and other reputational scholars is one in which realities of power are at variance with the democratic theory of political accountability. For instance, instead of decision making by elected office holders, power is wielded by economic dominants who may be relatively invisible to the public and not subject to electoral control. Thus, rather than a wide distribution of political power among the citizens, power is held by a relatively small upper class.

However, critics of this approach have charged that it predetermines its findings by incorporating the a priori assumption of single power elite. It is argued therefore, that it is no coincidence that the reputational model usually identifies single cohesive set of leaders. It is also pointed out that ignoring the possibility that power may vary from one policy domain to another, the reputational approach falsely assumes that the power structure identified controls the major issues. But the fact of life is that leadership could be specialized, and one group may be influential in one policy area and other groups in other areas. Moreover, the reputational model measures not power per se but rather the reputation for power. The approach, critics claimed, is primarily subjective rather than behavioral and empirical. It is against the backdrop of this plethora of criticisms of the reputational approach that the paper examined below the third major approach to the understanding of community power Structure.

\section{Decisional Approach or Model}

According to Dahl in [4], different issues tend to evoke participation of different individuals and groups. There are some degrees of overlap, which may not be very noticeably. Central to this finding, is the conclusion that decision-making is a group process, where different groups are concerned with different issues. Decision-making was considered by Dahl to extend beyond the loose definition of ruling offered by the elitists. It involves the processes of initiation, modification, and virtue.

The proponents of this model therefore, argued that to study power, we must at least examine the actual decisions and then determine those involved in the entire process. In other words, the process begins with the selection of certain key issues in the community followed by the identification of the people who seem significant in affecting their outcomes. To them it was not enough to claim, as the reputation model that certain individuals have the potential for control. One must find out whether they engage in the decision-making process.

For the purpose of this paper, we shall adopt the Decisional model to the study of community power structure as our theoretical framework. This theoretical framework has the following assumptions, which make it apt as our analytical framework:

I. Different issues would evoke the participation of different individuals and groups.

II. Decision-making is a group process, requiring the input of different stakeholders.

III. Power structure is so nearly monolithic and completely controlling as to exclude or completely render insignificant the role of women.

Using this model, therefore, the study captures and measures the level of women's participation in the dynamics of community power play through such indices as political participation, women's education; social and economic empowerment of women; role of women-focused NonGovernmental Organizations (NGOs) at community levels; etc.

\section{J. The Gender Dimension of Community Power Structure}

Gender issue is a subject of vital national importance. According to the current national population census, there are more women than men in Nigeria [5]. There is, therefore, no doubt that sustainable human development in Nigeria cannot be effective if more than half of the country's population that are women remain marginalized and discriminated against such that they cannot participate freely in the economic and political life of their communities and the nation in general. The pace of development around the world today has become so rapid that there had arisen many opportunities for women to constructively participate in areas of development where they can use their innovation, creativity and promote their social status without risking their position in the family or community.

Indeed, women play an outstanding role directly or indirectly in the national economic growth process. As the most prominent member of the family, women not only participate in the small-scale economic programs of their own family, but according to their social status, they determine the larger scale economic development courses of the country as well. For instance, while performing their family duties, many women also earn income for the family along with their husbands and thus contribute to the smooth running of the country's economic wheels. The picture of the Nigerian woman as a docile being, forever looking up to, obedient and dependent on her man, is a false picture of the Nigerian woman, created and sustained by the Nigerian men for some self-serving interests.

\section{K. Political Participation}

The Nigerian woman began the struggle to assert her rights long before it became the fashion among educated, radical women in the United States and Europe [6]. The Nigerian women had at various points in history refused that the place of their lot was in the kitchen and the kitchen alone. They had appreciated the undeniable fact that women have a role outside the kitchen too, as in politics and meaningful 
contributions to the social, economic, and political development of the Nigerian society.

The history of the participation of Nigerian women in leadership and by implication playing active roles in the dynamics of community power structure dated back to the pre-colonial period. The geo-political region now called Nigeria had famous and powerful Kingdoms and empires, some of which were ruled and controlled by women [6],[7]. The Hausa Empire was founded and controlled by Queen Amina of Zazzau in the 16th century. There was also UvwiEmotan who was a politician and diplomat of the Benin Kingdom, and Idia Esigie who through her political prowess successfully fought to restore her son as the Oba of Benin [7]. Oba Otompo reigned from 1555 and is the only known female Oba (political leader) in Yoruba land [7]. She was an influential figure who restored dignity, peace, and stability in Oyo Kingdom.

Madam Tinubu ruled from 1830-1887 and was a seasoned political stalwart [8]. She actively played a role in the resistance to British rule in Nigeria. In the $1860 \mathrm{~s}$, OjediUmdei emerged as a powerful leader of the Igalas. She was a formidable force to reckon with during the European invasion of Igala land.Similarly, OmuNavagbako was a political leader in Onitsha who helped the missionaries to promote Christianity in Onitsha and lobbied to prevent women from holding markets on Sundays. She signed a treaty between Queen Victoria of England and Onitsha in 1884 [8].

This trend of powerful Nigerian women continued up to the colonial time to include Alimotu; Obasa, Oloki, Funmilayo Ramsome-Kuti, Hajiya Gambo Sawaba; Margaret Ekpo, etc.Nigerian women had had a definite and distinct status in the society and contributed positively to the development of their communities.

\section{Women Associations}

Women even had powerful Associations e.g., the Ibibio women had "ibangIsong" which was the most potent women organization relating to matters of winning political, economic, and social privileges for women [7]. Under colonialism, there were several women Associations and Organizations. Through the umbrella of Women Associations, the Nigerian women fought and resisted the erosion of their power and influence as demonstrated by the Ibo and Ibiblo women in the famous 1929 Aba riot [9]. These women believing in a special type of immunity and utilizing their secret societies and markets to spread the revolt in which they tried to bring down the synthetic, British created system of chiefs that was insensitive to the political status of women [9].

\section{Political Marginalization of Nigerian Women}

The colonization of Nigeria changed the political fortunes of women in the country. When in the colonial era, the British government introduced electoral politics, Nigerian women were excluded [7]. Colonialism was, therefore, the midwife of the political marginalization of the Nigerian women.

However, in the 1954 elections, women of Southern Nigeria were allowed to participate but, in the North, women were still not allowed to vote or be voted for until Obasanjo's military government through a decree approved the universal franchise for women in 1976 [9]. During the First Republic, Nigerian women had no political space in the independent
Nigeria. They were still under domination particularly in the North where the ruling party, the Northern Peoples' Congress (NPC), did not allow women to participate in politics. NPC emotionally insisted that the domestic and not political space belonged to women. To support this position, some evoked the injunction of Islamic religion and argued that women were supposed to be in seclusion and therefore, could not participate in politics even as voters [9].

Others argued that politics was a dirty game and women as mothers of the nation needed not participate in politics. This was to enable them to keep the ideals, culture, and purity of the nation so that the nation does not get corrupted. Women in the Northern Nigeria, therefore, could not participate in politics until 1976. The exception was female members of Northern Elements Progressive Union (NEPU) under the leadership of late Mallam Aminu Kano. By its own ideology, NEPU was a progressive party and fully supported the participation of women at all levels. The first generation of NEPU women supporters like Hajiya Gambo Sawaba and Ladi Shehu were prominent members of NEPU. But that participation was at a high price. For instance, just because of her participation in politics, Sawaba was jailed more than 17 times and even expelled from the City of Kano by the then Emir of Kano [9].

The overall participation of women in politics after independence was marginal. While there was token involvement of women in the political arena in the South, the women in Northern Nigeria were virtually excluded.

\section{N. United Nations Decade for Women, 1975-1985}

The United Nations Decade for Women, 1975-1985, aroused the interests of governments in the role of women in development. During this period, the government showed much interest in promoting women participation in development by appointing them into various positions and policy-making bodies.

The main objective has been to bring about equality, justices, inclusiveness, and full participation of women in development.

Today, Nigerian women are not only forces to be reckoned with in the development of their various communities but had established their presence in almost every profession, respectable or otherwise. In academics, we have female ViceChancellors, Professors, Dean of faculties and Heads of Department. In journalism, women editors and publishers abound. We also find women in the Military, the Police, Custom and exercise and Immigration. They are also in leading positions in banks and insurance companies as well as industries and commerce.

Women have equally, a loud and visible presence in politics today. For instance, in the Second Republic and especially since 1999, we have had Women Vice-Presidential candidates, Speakers of State Houses of Assembly, female Deputy Governors, Ministers, Commissioners, Special Advisers and Special Assistants. In the civil service, we have had female Permanent Secretaries and Heads of Ministerial Department. A Nigerian woman, Dr. Ngozi Okonjo Iwela is currently the President of the World Trade Centre. 


\section{O. Social and Economic Empowerment of Nigerian Women}

The United Nations (UN) through its various organs and agencies has recommended concrete measures designed to emancipate women from age-old bondages and integrate them into the mainstream of national development efforts of countries. In Nigeria, the Federal and State Governments have implemented policies which are designed to affect the full participation of women in development. For instance, the introduction of such programs as the "Better Life for Rural Women" in 1987 as well as the setting up of the National Commission for Women in 1990 paved way for the participation of women in the national affairs of Nigeria. The Better Life for Rural Women program was aimed at empowering women in the rural areas economically. In 1998, the National policy on women was promulgated designed to protect women against all forms of discrimination.

Nigeria had promulgated policies in the educational, health, employment, agriculture, cultural and industrial sectors to give women a sense of belonging. To ensure that these policies were fully implemented, it was incorporated in chapter 11 section 17 sub-section 2 of the 1999 constitutions (as amended). It states that every citizen shall have equality of rights, obligations, and opportunities before the law irrespective of the gender. Also, the educational policy makes it mandatory for women to be given proper education. The high light of the policy was that the Nigeria women should enjoy the full benefits of contemporary living. They require basic education to contribute meaningfully to the development of the country. In fact, the broad thrust of the National Policy on Women was the adequate representation of women in all spheres of decision-making process, the empowerment of women to enable them to become selfreliant and self-sufficient, support for small, medium, and large-scale enterprises for women as well as the opening up of new opportunities nationally and internationally to women in Nigeria.

The 1995 Beijing Declaration to which Nigeria was a signatory provided that $30 \%$ of all positions in government and government owned concerns and structures be given to women. Indeed, if the affirmative action of the National Policy on Women is observed to the letter, for every ten appointments; at least three must be women. However, in the Civil Service for instance, statistics released by the National Centre for Women Development (NCWD) in 1992, showed that women constituted only $05 \%$ of all senior Administrators and Managers in the country [5], a position that is still current. The political landscape in Nigeria therefore, featured an almost total male domination in all spheres of life. This is true of both civilian and military regimes, as the military were no more sympathetic to the cause of women than the politicians.

\section{P. Women Education}

In all countries of the world, education is now recognized as the main vehicle for promoting and improving the status of women. This new interest in the education of women is part of a general awakening that has taken place during the last two decades. People now realized that sustainable human development cannot be effective if half of the human race (the women folk) remain ignorant, marginalized and discriminated against. The importance of women education can, therefore, not be over-emphasized. Education will enable women to effectively fulfill their gender role and participate in the affairs of the society. For instance, according to Adesola Fadehan (Project Coordinator, Women Network Caucus, an (NGO):

If we can achieve a higher percentage of literacy among women especially at the grassroots, the problem of women will be half-solved [5].

Nigeria has indeed, embarked on many education programs aimed at the development of her women folk. Such programs include adult and non-formal and formal education. The aim is to build the capacity of women and produce corps of women politicians who will contest and win elections.

However, using our Decisional Analytical Framework, we observed that the political awareness of the Nigerian women as well as their increasing level of literacy have not translated into a high level of their involvement in public decisionmaking. This deduction may be better understood against the backdrop of such indices of political participation as:

- holding party or public office;

- being a candidate for political office;

- soliciting political funds;

- attending caucus or strategy meetings;

- becoming active members of political parties;

- contributing substantial time and resources to political campaigns;

- monetary contributions to parties/ candidates;

- wearing party button or stickers.

- persuading others to vote in a certain way.

- voting in elections.

- exposing oneself to political stimuli.

Using these indices as a measure, it is obvious that Nigerian women, even though politically active, are mainly at the level of exposure and voting. This trend extends to their involvement in the operation and structure of community power where not much level of participation is delivered by women in community decision-making.

\section{CONCLUSION AND RECOMMENDATIONS}

It cannot be denied that women did and still do more than their fair share of the work in the fields and in the homes. But they are nonetheless regarded, especially in traditional societies, as having a place in the community which is not only different but also to some extent, inferior. By virtue of their sex therefore, women in Nigeria suffered from inequalities which have nothing to do with their contributions to the family or community welfare.

Accordingly, if women are to become major players in the dynamics of community power structure through their participation in decision-making, they must participate in areas traditionally and socially considered, the exclusive preserve of the men, such as security, defense, right of inheritance, and so on. This will enhance the socio-economic and political status of women and impact significantly on their roles in the dynamics of community power game. In this respect, we suggest that: 
- There should be massive campaign and mobilization programs to sensitize policy- makers and others to gender issues. Most people are simply not aware of gender issues and their impact on the overall development of the nation.

- There should be needs assessment survey of target beneficiaries to guide the choice of gender sensitive programs.

There should be efforts geared towards more functional programs of education for women so that beneficiaries can become either self-employed or find employment easily in other establishments.

\section{REFERENCES}

[1] A. Ohiri, Enhancing Women's Contribution towards National Development through United Nation's Agencies, Enugu Acena Publishers, 2000.

[2] Unesco, the State of Education, 2000

[3] M. C. Margaret, "Political analysis: An introduction," (2 $2^{\text {nd }}$ Edition). London,

[4] Allyn \& Bacon Inc, 1972.

[5] R. Lineberry, "Urban politics and public policy," NewYork, Harber\& RowPublishers.

[6] Newswatch, "Perspective on women issues in Nigeria," 2000.

[7] D. A. Ilyavyar, "Women in leadership and decision-making in Nigeria, 1960 to date," Paper Presented at a Workshop on Gender, Violence and Family Poverty held at Arewa House, Kaduna, 2001.

[8] M.Tukur, Women and Poverty in the third world; An assessment of the Beijing experience (unpublished Ph.D Thesis) BUK, Kano, 2003.

[9] A.M. Yakubu et al. "The United Nations at 50: An appraisal," proceedings of a seminar organized by Kaduna Polytechnic, Kaduna in collaboration with the UNO's Office in Nigeria held at Arewa House, Kaduna, $16^{-} 18^{\text {th }}$ January 1996.

[10] A. Bolanle, "Nigerian women in historical perspective," Lagos, Sankore/Bookcraft, 1992

[11] A. Agina-Ude, "Strategies for expanding female participation in the 2003 elections and beyond," Nigerian Social Scientist, 6(1), 3-7, 2003.

[12] O. Nweze, "Relative deprivation of the Nigerian female personality as gender violence: A Nigerian overview," Paper presented at a national workshop on gender violence and family poverty, $9^{\text {th }}$ July 2001. Kaduna, Arewa House.

[13] Northern Nigeria Educational Research Project (NERP), "Towards the improvement of girl child and women education in the northern states of Nigeria: Agenda for action," 2002.

[14] S. Sulaiman, "Effective management of local government: A manual for grassroots development," Kano, Samarib Publishers. Report of the Political Bureau, 1987.

[15] B. Micheal, "Political systems and the distribution of power," London. Tavistock Publication, 1965.

[16] T. Halima, "Nigerian women in a changing world: Challenges and prospects," A paper presented at a monthly lecture series organized by British Council/CRD, Kano, 2003.

[17] C. Kate, "The fractured community landscapes of power and gender in rural Zambia," London, University of California Press Ltd, 1997. 